\title{
Parental financial support : A safety net for young adults with debt problems
}

\section{Majamaa, Karoliina}

2019-07

Majamaa , K \& Rantala , K 2019 , ' Parental financial support : A safety net for young adults with debt problems ' , International Journal of Consumer Studies, vol. 43 , no. 4 , pp.

379-389 . https://doi.org/10.1111/ijcs.12517

http://hdl.handle.net/10138/327467

https://doi.org/10.1111/ijcs.12517

unspecified

acceptedVersion

Downloaded from Helda, University of Helsinki institutional repository.

This is an electronic reprint of the original article.

This reprint may differ from the original in pagination and typographic detail.

Please cite the original version. 
DR. KAROLIINA MAJAMAA (Orcid ID : 0000-0002-0503-5611)

Article type : Original Article

\title{
Parental financial support: a safety net for young adults with debt problems
}

Key words: Young adults, beneficiaries, debt problems, parental financial support

\section{Authors:}

1. Karoliina Majamaa

Institute of Criminology and Legal Policy, University of Helsinki

P.O. Box 24, (Unioninkatu 40), FI-00014 University of Helsinki, Finland

Tel. +358505779480

karoliina.majamaa@helsinki.fi

2. Kati Rantala

Institute of Criminology and Legal Policy, University of Helsinki

P.O. Box 24, (Unioninkatu 40), Fl-00014 University of Helsinki, Finland

Tel. +358 503876198

kati.rantala@helsinki.fi

\begin{abstract}
Parental financial support benefits young adults in societies with decreasing welfare-state support and a pattern of early home-leaving. This article focuses on the association between young adults' debt problems and parental financial support: the extent to which indebted young adults receive financial help from their parents. We also investigate the extent to which specific benefits are associated with debt problems or parental financial support. The data were gathered in an online survey conducted among 18-to-35-year-old Finns $(n=1,019)$. The results revealed, first, that many parents
\end{abstract}

This article has been accepted for publication and undergone full peer review but has not been through the copyediting, typesetting, pagination and proofreading process, which may lead to differences between this version and the Version of Record. Please cite this article as doi: $10.1111 /$ ijcs. 12517

This article is protected by copyright. All rights reserved. 
safeguard their indebted adult children's lives by means of financial support and second, that heavy cash-welfare-benefit users are particularly likely to receive parental financial support. Our analysis also revealed that the prevalence of debt problems as well as of parental financial support were especially high among those who had received social assistance, sickness benefit or labour-market subsidy within the previous 12 months. In a society open to new social risks as well as to debt problems, young people who lack financial support from their parents have a rockier transition to adulthood than those who receive support.

Key words: Young adults, beneficiaries, debt problems, parental financial support

\section{INTRODUCTION}

Social risks nowadays include, among other things, precarious employment, being a member of the working poor, long-term unemployment, single parenthood and the inability to reconcile work and family life (Bonoli, 2007). The emergence of these 'new social risks' seems to be strongly associated with fragile employment and family change, and to concern young adults, specifically those with low or obsolete skills and/or under-age children (Taylor-Gooby, 2004; Bonoli, 2007; Barbieri \& Bozzon, 2016). Despite the high capacity of the Nordic welfare states to provide protection against social risks, the level of benefits and allowances declined considerably following the recession of the 1990s (Moisio, 2008). It appears that parental financial support has at least narrowed the gap in funding resulting from the reduction in contributions from Nordic welfare states to young adults in a vulnerable position (Majamaa, 2011). Even so, recent financial developments, especially the extension of consumer credit to low-income households and wage earners (Allon, 2015), easily lead to reliance on credit and consequently to debt problems. In other words, young adults who incur debts to cover the costs of education, housing and consumption are under more financial pressure in the current societal situation (see e.g. Oksanen et al., 2015).

Many studies have shown that, on average, financial difficulties and debt problems are common not only among young adults, but also among those in the lower social strata, especially if they have child(ren) (Patel et al., 2012; Xiao et al., 2014; Oksanen et al., 2015). Neither a low educational level nor a low income (or having children) automatically leads to debt problems: students, for example, comprise an interesting low-income group in this regard. Even if some studies (see e.g. Worthy et al., 2010) report that students have a high risk of encountering severe financial problems and overindebtedness due to the easy availability of credit, rising tuition fees and a declining economy,

This article is protected by copyright. All rights reserved. 
Finnish statistics show that students have relatively few debt problems (Statistics Finland, 2017). One possible reason for this is that many young adults are financially semi-dependent (Furlong \& Cartmel, 2007): parents in particular are providing financial, housing and other assistance to their studying adult children well beyond the age of majority, even if their responsibility for maintenance generally ends after a child reaches the age of 18.

Children are very likely to receive parental financial help as young adults, and the amount of help decreases rapidly with the age of the child (as well as of the parent). Previous Nordic studies have investigated the interrelationship between public and private financial support (Björnberg \& Latta, 2007; Majamaa, 2011). The results indicate that private support, or to be more precise, parental financial support to adult children, is somewhat complementary in nature. Indeed, it is given to young adults on a low income in particular (Björnberg \& Latta, 2007; Majamaa, 2011), but the need for help is not the only motive: approximately 25 per cent of help givers provide money for 'no reason at all' (Björnberg \& Latta, 2007). Love and concern for the wellbeing of the recipient are apparently the main motives behind helping. In other words, maintaining social and emotional relationships is a major condition for intergenerational support, although altruism, solidarity and reciprocal aspects have also been highlighted in previous studies on intergenerational help (Kohli, 1999; Björnberg \& Latta, 2007; Majamaa, 2011; Silverstein et al., 2012; Kalmijn, 2013).

Even if the complementary role of parents as welfare providers in the lives of young adults has been recognised in previous studies (see e.g. Kohli, 1999; Björnberg \& Latta, 2007; Majamaa, 2011), there is no evidence that debt problems, which seem to be very common among young Finns with a low level of education (Oksanen et al., 2015; Majamaa et al., 2019) and are poorly recognised by the welfare state (Social Insurance Institution of Finland, 2018), promote parental financial support. Nor have any attempts been made to find out if receiving various cash-welfare benefits is associated with debt problems or parental financial support. In this article, therefore, we investigate the association between heavy welfare dependence and parental financial support. Our study is based on Finnish data gathered in an Internet survey conducted in the spring of 2015 ( $n=1,019)$. Young adults are defined here as those who are in the transition phase to adulthood and are aged between 18 and 35 years.

The article comprises five sections. In the section following this introduction we present some Finnish statistical figures related to young adults' debt problems, as well as previous research results on the issue, and give a brief account of parental financial support and related study findings. The third section describes the research design, sets out the specific research questions, and gives an overview of the data, variables and methods used. The focus in the fourth section is on debt

This article is protected by copyright. All rights reserved. 
problems and parental financial support, including their associations with received cash-welfarebenefits. The article ends with a discussion based on the results of the study.

\section{THE MULTIDIMENSIONAL NATURE OF YOUNG ADULTS' DEBT PROBLEMS AND PARENTAL FINANCIAL SUPPORT}

\subsection{Debt problems among young adults}

According to Finnish statistics (Suomen Asiakastieto Oy, 2017), approximately nine per cent of all 2024-year-olds had at least one payment default ${ }^{1}$ at the end of December 2016. Default was most common among 25-29-year-olds (13.3\%) and 30-34-year-olds (13.1\%). Within these three age groups, it was more common among men than women. The proportion of persons with payment defaults decreased gradually in the older age groups: among 50-54-year-olds, for example, it was 10.7 per cent, and in the oldest age category (70 years and above) it was 1.6 per cent (Suomen Asiakastieto Oy, 2017). Another way of assessing the prevalence of debt problems is in terms of debt-enforcement ${ }^{2}$ rates. The highest percentage on the last day of December 2016 was among unemployed young adults (15.2\%), classified as 25-34-year-olds, whereas the rate was five per cent (4.7\%) among those who were employed (Statistics Finland, 2017, the author's own calculations). Seven per cent of students (7.4\%) were subject to debt enforcement at the end of 2016.

Oksanen and his colleagues (2015) drew a more extensive picture of the prevalence of debt enforcement. They found that it was most common among 19-to-24-year-olds and least common among 50-to-64-year-olds (the oldest age group in the study). Approximately 14 per cent of those in the youngest age group had at least one debt enforcement in 2013, compared with 12 and 13 per cent, respectively, among those between the ages of 25 and 29, and 30 and 39 . The percentages doubled over a longer nine-year time-span among young adults (2005-2013). Approximately 28 per cent of those in the youngest age group (19-24-year-olds) had at least one debt enforcement during that period, and approximately 25 per cent of those in the two older age groups had serious problems with their debts.

\footnotetext{
${ }^{1}$ In Finland, creditors must take legal action if they want the unpaid debt/bill to be paid. Payment default is a note in a register indicating that someone has arrears, resulting mainly from a court decision or debt enforcement.

${ }^{2}$ Following the court decision, creditors can request the Finnish enforcement authority to take measures. Private judicial claims cover a wide variety of overdue bills such as consumer credit, phone and electricity bills, rent and condominium payments, whereas public debts to the state include public-healthcare payments, penalty fees, taxes, and insurance premiums. The latter are collected by enforcement without a separate court judgement.
}

This article is protected by copyright. All rights reserved. 
It seems that the early home-leaving pattern in the Nordic countries in particular increases the risk of poverty (Aassve et al., 2006; Aassve et al., 2013), as well as of debt problems (Oksanen et al., 2016). Mendola and her colleagues (2009) found that poverty peaks after moving out of the parental home but falls quite sharply in subsequent years. Debt problems have also been found to increase rapidly six months after leaving the parental home; those who move out at the age of 18 or younger face more problems than those who move out at an older age (Oksanen et al., 2016).

Life in general is unpredictable, however, and unexpected life-situation changes may jeopardise fragile finances. Losing one's job, illness or the breakdown of a relationship, for example, tend to increase the risk of financial difficulties, as well as debt problems (Townley-Jones et al., 2008; Patel et al., 2012; Hiilamo, 2018). Indeed, people with debt problems may well have severe financial difficulties even if the welfare state is supposed to help them to maintain their living standards (Oksanen et al., 2015).

\subsection{Parental financial support}

Help from close kin and family members seems to be motivated by love and affection, solidarity and altruism (see e.g. Rossi \& Rossi, 1990; Becker, 1993; Kohli, 1999; Björnberg \& Latta, 2007; Kalmijn, 2013; Majamaa, 2015). Altruism implies the giving of help to those in need without expectation of repayment (Silverstein et al., 2012), and parent-child relationships in particular are often assumed to be altruistic (Becker, 1993). Altruistic behaviour in the family has benefits - altruism insures family members against life's uncertainties (Becker, 1981; Kohli, 1999). Even if parents have altruistic motives in helping their adult children and do not expect any immediate payback, their altruistic behaviour may well be reciprocated in later life (see e.g., Kohli \& Künemund, 2003; Kalmijn, 2013). In short, even if parents do have altruistic motives, intergenerational support is usually based on generalised reciprocity (Sahlins, 1972).

On the aggregate level, solidarity and transfers between generations could be considered a type of intergenerational contract (see e.g., Bengtson, 1993; Kohli, 1999). Indeed, the social risks are greater at the beginning and the end of the life course when the ability to respond to them is weaker. During its productive years each generation supports generations that are dependent and need more help, and the public sphere regulates the transfers. For example, via their taxes middle-aged people pay relatively more towards the welfare of small children, education and care for the elderly than other age groups, and they make relatively less use of these services. Even so, they can assume that they will receive pensions, healthcare and so on when they are older and need them (Bengtson, 1993; Kohli, 1999).

This article is protected by copyright. All rights reserved. 
Western European countries can be roughly categorised into three support or transfer regimes based on their private and public support patterns: Northern, Southern and Central Western (Brandt, 2013; Albertini \& Kohli, 2013). These regimes overlap with welfare regimes to a great extent (see e.g. Esping-Andersen, 1990), and that the prevalence of public assistance in particular explains differences in 'support regimes' (Brandt, 2013) or 'transfer regimes' (Albertini \& Kohli, 2013). In short, intergenerational support is more likely to be considered obligatory and inevitable in Southern and Central Western Europe than in Northern European countries (Brandt, 2013).

According to Albertini and Kohli (2013), the aims and meaning of parental financial support differ across the transfer regimes. Children tend to leave the parental home early in Northern European countries, ${ }^{3}$ parental financial help is direct and explicit, and is provided voluntarily, whereas parentchild co-residence is less normative as a support strategy. The opposite is the case in Southern European countries: parents support their adult children mainly through prolonged co-residence and give little financial support after they leave the parental home. Central Western European countries lie in-between the two regimes: on average, adult children leave the parental home at an older age than in Northern European countries, but they receive frequent financial support if they need help on account of being in education or unemployed.

Accordingly, young adults' living costs and financial situation usually change considerably after they move out of the parental home, which in Finland is reflected in their high poverty rates (Statistics Finland, 2018). Poverty rates are remarkably high among people in their early 20s; rising to almost $30 \%$ in Finland (Aassve et al., 2006). Even if parental financial support tends to go especially to those in need - young adults under the age of 25 who live alone, are students, and are unemployed and/or on a low income (Björnberg \& Latta, 2007; Majamaa, 2012; Myllyniemi, 2015) - parents differ in their ability and willingness to give support. Björnberg and Latta found (2007) that families with a lower socio-economic position (a low level of education and a low income) provided less financial support to their young adult children than other families did (see also Majamaa, 2012).

Previous Nordic studies have also revealed that daughters tend to receive more parental financial support than sons (Fritzell \& Lennartsson, 2005), although this gender effect is not evident in all studies (Björnberg \& Latta, 2007; Majamaa, 2012). Furthermore, the need for parental support changes at different ages and in different life phases. Young adults living alone seem to rely more on their parents, whereas after forming a relationship they appear to become less dependent. Overall,

\footnotetext{
${ }^{3}$ For example, the average age at which young people left the parental home In Finland in 2015 was 21.9 years, compared with 26.1 years in the European Union (EU) (Eurostat, 2017). Many individual-based state benefits, such us the student grant, housing and unemployment allowances, and the availability of housing appear to facilitate the early home-leaving pattern in Finland.
}

This article is protected by copyright. All rights reserved. 
completing one's studies, establishing a more permanent presence in the labour market and earning a higher income, as well as becoming a parent, considerably decrease the proportion of young adults who receive parental financial support. (Majamaa, 2015.)

The ideology behind the Finnish welfare system is that the state carries the main responsibility for the economic welfare of individuals, including young adults ${ }^{4}$, who are not able to provide for themselves. In other words, the Nordic welfare state income-maintenance system aims to guarantee insurance against income loss during life-situation changes (see e.g. Kangas \& Kvist, 2013). Even so, the Finnish welfare state does not readily recognise debt problems. For example, unpaid short-term debts are not included in calculations of social assistance, a last-resort financial benefit (Social Insurance Institution of Finland, 2018). Indeed, statistics and studies show that young Finns nowadays who are studying, are unemployed, have no qualifications and/or have dependent children increasingly face financial difficulties (Statistics Finland, 2016a), and debt problems (Oksanen et al., 2015).

Parental financial support may be direct or indirect. An indirect but very visible form of support is to allow adult children to live in the parental home free, or virtually free, whereas giving money, buying goods and paying bills represent more direct support, which is nevertheless less visible outside the family (Swartz \& O'Brien, 2009; Majamaa, 2015). As previous studies have shown, parental helping is strongly related both to the needs of adult children and to the parents' resources and willingness to give direct financial help. We aim to find out if debt problems are included in these needs. In the context of the Nordic welfare state, parental financial support has been found to be at least somewhat complementary to the support system, and social assistance has been found to have relevance to private help when parental help extends over a wide age range. There is also evidence that parental financial support complements social assistance (Björnberg \& Latta, 2007). We aim to find out if the parental financial support complements also other welfare-state cash-benefits than social assistance.

\subsection{Study design and specific research questions}

Our specific focus in this article is on cash-welfare benefits, heavy welfare dependence, debt problems and parental financial support among young adults in Finland. We address the following three research questions:

\footnotetext{
${ }^{4}$ Post-compulsory education is largely state-provided in Finland: tuition is free of charge and students are provided with many state benefits, such as a study grant and a housing supplement, which are not paid back. The government-guaranteed student loan is a normal bank loan granted by banks upon application.
}

This article is protected by copyright. All rights reserved. 
1. How are different cash-welfare benefits associated with the prevalence of debt problems as well as with parental financial support?

2. Is heavy welfare dependence associated with parental financial support as well as with debt problems?

3. Do indebted young adults receive more parental financial support than young adults without debt problems?

Previous studies have confirmed that parental financial support tends to be complementary to support provided by the welfare state (Björnberg \& Latta, 2007; Majamaa, 2012). We assume that the prevalence of debt problems as well as parental financial support vary significantly depending on the type of cash benefits the young adult has received. We also assume that heavy welfare dependence, measured in terms of an increasing number of cash-welfare benefits received, is positively associated with parental financial support. Previous studies have also pointed out that parents financially support their adult children in need, especially those who are unemployed or are still studying (Björnberg \& Latta, 2007; Majamaa, 2012), and we assume that debt problems are included in these needs.

\section{DATA, VARIABLE AND METHODS}

\subsection{Data}

This study is based on information obtained from an Internet survey 'Young adults and debts'. The survey was targeted at young adults aged from 18 to 35 who lived in Finland in the spring of 2015. The link to the survey was distributed in two different ways, by different organizations and by mail. First, it was sent to various organizations that were in contact with young adults in different life phases and financial situations, such as youth, student and labour-market organizations, the Finnish Defence Forces, employment offices and debt counsellors. With the help of these contacts, of the 822 respondents, 741 gave adequate answers in the questionnaire. Second, we ordered a random sample from the Finnish Population Register Center, including contact information, of 3,000 young adults between the ages of 18 and 35. We sent each of them a postcard giving information about the survey and a link to the online questionnaire. This yielded 286 respondents, of whom 278 gave adequate answers.

The data includes completed questionnaires from 1,019 respondents. However, because we excluded all those who did not answer questions concerning their socioeconomic position (qualifications, main type of activity and disposable income), the data to be analysed covers 901 young adults. Obviously, this is not representative of 18-35-year-old Finns. According to the

This article is protected by copyright. All rights reserved. 
comparisons of the data and official demographic statistics, men and those with no qualifications are under-represented (Majamaa \& Rantala, 2016). For example, according to the educational structure of the population (Statistics Finland, 2016b), in 2015, 16 per cent of Finnish adults between the ages of 30 and 34 had no post-compulsory-school qualifications, whereas the proportion in our data was three per cent (results not shown). Given that, on average, men have more debt problems than women, and those with a low educational level are at risk of over-indebtedness (Oksanen et al., 2016), the data underestimates debt problems (see also Majamaa \& Rantala, 2016). On the other hand, the percentage of young adults who receive parental financial support was at the same level as reported in other recent Finnish studies (Majamaa, 2012; Myllyniemi, 2015). However, even if the data is not representative, especially concerning groups with the most serious problems, it is still possible to assess the association between debt problems and parental financial support. We also kept non-response bias in mind in our interpretation of the results.

\subsection{Dependent and independent variables}

This study concerns one dependent variable - parental financial support. Information on parental financial support was obtained from the questionnaire items: "Has anyone close to you helped you financially, e.g. lent or given you money, or paid your bills/purchases in last 12 months?" and "Who?". The prevalence of parental financial support was categorized as one (1) if the respondent had received at least some maternal or paternal support during the previous 12 months. If not, the variable was categorized as zero (0). In relation to these questions, financial support only covered direct monetary help or similar support, and excluded living and eating in the parental home, for example. We could not obtain any information about the amount of financial support.

The choice of nine control variables was based on previous research and the data set. The first four sociodemographic variables were: age group (18-21, 22-25, 26-30 and 31-35 years); gender; type of household (living alone, with a spouse, with parent(s) or other); and children ('no' or 'yes'). The next three variables were related to socioeconomic characteristics: educational qualifications (vocational school or less, matriculation examination, at least a university of applied sciences); main type of activity (mainly working, mainly studying, studying and working, and out of the labour market); and disposable income per month (less than $€ 500$, $€ 500-999, € 1,000-1,999$, and $€ 2,000$ or more).

\footnotetext{
${ }^{5}$ Ten different alternatives were mentioned: a partner, a live-in or marriage partner, mother, father, father- or mother-in-law, grandparent(s), sibling(s), other relative, friend/godfather/-mother, somebody else, who? The respondent could select more than one response alternative.
}

This article is protected by copyright. All rights reserved. 
The final set of questions related to in-cash social security benefits and debt problems. Information on social-security benefits was obtained from the questionnaire item: "Which social-security benefits have you received within the last 12 months?" Fourteen response alternatives were given: earningsrelated unemployment benefit, basic unemployment benefit, labour-market subsidy, student grant, student housing allowance, general housing allowance, social assistance, sickness benefit, child benefit $^{6}$, child maintenance allowance/child support ${ }^{7}$, maternity/paternity allowance, parental allowance, child home-care allowance, survivor's pension. The number of benefits was categorised in four groups: $0,1,2$ and at least 3, the idea being to differentiate heavy welfare users from respondents who received no or only one or two cash-welfare benefits. The prevalence of debt problems was categorised as one (1) if the respondent had at least one of the following financial problems: significant difficulties in paying back loan(s), payments in a debt-collection process, previous debt enforcement(s), or at least one payment default. If the respondent had none of these problems, the variable was categorised as zero (0).

\subsection{Methods}

Our methods included descriptive statistics (Tables 1 and 2) as well binary logistic regression analysis (Table 3). Table 1 presents all the descriptive statistics related to debt problems and parental financial support, but we focus especially on the associations between the number of benefits and debt problems / parental financial support. We used cross-tabulation to determine the associations between specific benefits and debt problems as well as parental financial support (Table 2). We calculated chi-square statistics to identify any statistically significant differences among those who had debt problems as well as among those who received financial support from their parent(s) related to specific benefits.

The response variable in the logistic regression analysis was dichotomous: those who did (1) and did not $(0)$ receive parental financial support. Odds Ratios (OR) are presented for the logistic regression analyses, and the number of stars shows their statistical significance. In model 1 (Table 3), we took each main effect separately into the models, and adjusted the age and gender variables. To control for all the characteristics of young adults under consideration, we fitted all the main effects into the models (Table 3, Model 2). Stata 14 software was used in all the analyses.

\footnotetext{
${ }^{6}$ Child benefit was not included in this variable (Table 1): it is payable for every child living in Finland who is covered by Finnish social security until the age of 17. Child benefit was included in Table 2.

${ }^{7}$ Child maintenance allowance is benefit paid by the Social Insurance Institution of Finland to provide economic security if the child does not receive child support from the parent who is liable for maintenance. The amount of Child support is based on an agreement or a court decision, payable by the parent liable for maintenance in respect of his/her child.
}

This article is protected by copyright. All rights reserved. 


\section{FINDINGS}

\subsection{The descriptive part - debt problems and parental financial support}

Approximately 12 per cent of the young adults in this study had debt problems (Table 1). However, according to information obtained from Finnish statistical sources (Statistics Finland, 2017; Suomen Asiakastieto Oy, 2017) the prevalence of debt problems among young adults should be higher than this $^{8}$. This finding may relate to the fact that younger men with a low level of education were underrepresented in the survey (Majamaa \& Rantala, 2016). In other words, the prevalence of debt problems may well be higher among non-respondents, who tend to be young and male, with a lower educational level than their counterparts who respond (see e.g. Tolonen et al., 2006).

Debt problems were significantly lower among students (from six to seven per cent) than among those who were in paid employment $(12 \%)$ or out of the labour market $(22 \%)$. Table 1 also reveals a considerably higher prevalence of debt problems among young adults who received at least three welfare benefits (34\%) than among those who had not received any $(9 \%)$, one $(9 \%)$ or two $(8 \%)$ benefits during the previous 12 months.

Approximately 60 per cent of the respondents received at least some financial support from their parent(s), a percentage that has been at approximately the same level in previous Finnish studies (Majamaa, 2012; Myllyniemi, 2015). We further found that parental financial support was most common among those who were mainly studying $(72 \%)$ or out of the labour market $(74 \%)$, whereas less than half of those who were mainly working received support (38\%). When we looked more closely at heavy welfare dependence we found that the prevalence of parental support was clearly higher among those who had received at least three benefits during the previous 12 months (77\%) than among those who had received no benefits (42\%) or just one (54\%). Support was also more common among respondents who had debt problems (69\%) than among those who did not (57\%).

We noticed that a high number of cash-welfare benefits was associated both with debt problems and with parental financial support (Table 1). Table 2 shows more clearly how single benefits are associated with debt problems and parental financial support.

\footnotetext{
${ }^{8}$ The percentages obtained from Suomen Asiakastieto Oy (2017) and Statistics Finland (2017) give only one dimension of debt problems (age-related percentages of payment default and debt-enforcement). In the 'Young adults and debts' survey the questions related to debt problems are based on four-dimensions: respondents were categorised as having debt problems if they had at least one of the following financial problems: significant difficulties in paying back loan(s), payments in a debt-collection process, previous debt enforcement(s), or at least one payment default.
}

This article is protected by copyright. All rights reserved. 
As Table 2 reveals, debt problems were common especially among those who had received social assistance $(64 \%)$ or child maintenance allowance/child support $(48 \%)^{9}$ during the previous 12 months. They were also prevalent among young adults who had received basic unemployment benefit (34\%). Our results revealed low levels of debt problems among students, or at least among those who receive a student grant or a student housing allowance: approximately seven per cent of them had such problems, whereas the overall level was 12 per cent (see also Table 1).

As expected, parental financial support was especially prevalent among the young adults who had received social assistance (81\%), but the percentages were also high among recipients of sickness benefit (81\%) and a labour-market subsidy (79\%). In addition, recipients of a student grant $(72 \%)$ and student housing allowance (75\%) were particularly likely to receive parental financial support. Even if financial support from parents seemed to complement many cash-welfare benefits, supplementary support was less prevalent when the recipient become a parent (Table 2).

As expected, debt problems (5\%) and parental financial support (41\%) were both less prevalent among the respondents who did not receive any cash-welfare benefits. This result gives further evidence of the complementary nature of parental financial support: young adults who fend for themselves financially (do not need welfare-state support) are less likely to receive parental financial support. Results also revealed that especially lone parents who are the recipients of child maintenance allowance/child support need help from the welfare state more generally, or from their own parents: at least the lack of (enough) financial support seemed to promote debt problems among this group.

\subsection{The explanatory part - indebted young adults in particular receive parental financial support}

It was not surprising that the association between age and parental financial support became weaker in the full model: the older age groups reported less parental financial support than the youngest one. Financial support was also more prevalent among women than among men (Table 3, Model 2). When all the variables were included in model 2 , we found no association between type of household and parental financial support. Even so, all young adults who live in their parental home receive at least some indirect financial support. We found no association between having children and receiving parental financial support, even if debt problems were common in families who received at least one child-related benefit (Table 2). Support seems to change in form during this

${ }^{9}$ These results should be interpreted with caution, however, given the very low number of young adults in the data who received this allowance $(n=25)$.

This article is protected by copyright. All rights reserved. 
phase of life: diminishing parental financial support is replaced with childcare help (Majamaa, 2015), which may be reflected in our results.

The prevalence of parental financial support was higher among the more highly educated than among those with no more than a vocational-school qualification. Indeed, previous studies have shown that highly educated parents are more inclined and more able to provide financial support to their adult children than those who are less highly educated (Björnberg \& Latta, 2007; Majamaa, 2012), which may be reflected in the above-mentioned result. Furthermore, the association intensified after the debt-problems variable was included in the model (results not shown), which implies that more-highly-educated young adults in particular receive parental financial support if they have debt problems. A general upper-secondary education (leading to the matriculation examination) is still the main pathway to higher education, and most upper-secondary-school pupils in Finland continue their studies after matriculation. Matriculation from general upper-secondary school does not give any occupational or professional qualification, however, and this may affect the prevalence of parental financial support in the first place (Table 3).

The association between the main type of activity and parental financial support became weaker and it did not remain statistically significant in model 2. Even so, there is some evidence that respondents who were out of the labour market were more likely to receive financial support than their employed counterparts. Not surprisingly, parental financial support was less generous among those with a higher income than among those whose disposable income was less than $€ 500$ per month (Table 3, Model 2). Indeed, low income seems to predict more parental financial support than being a student or being out of the labour market.

The data also confirms the association between an increased number of social-security benefits and parental financial support. In other words, it seems that heavy welfare users are particularly likely to receive financial support from their parents. Furthermore, debt issues seem to be among the problems that parents support financially: Table 3 (Model 2) shows that parental financial support is more prevalent among young adults who had debt problems than among those who did not.

\section{DISCUSSION}

According to our results, approximately 10 per cent of the young adults investigated in this study had debt problems, and approximately 60 per cent of the respondents received at least some direct financial support from their parent(s). Debt problems were less common among those who were

This article is protected by copyright. All rights reserved. 
living with their parent(s), were studying and did not receive any cash-welfare benefits (see Tables 1 and 2). Furthermore, the prevalence of parental financial support was highest among those in their early twenties, whose disposable income was low (see also Björnberg \& Latta, 2007; Brandt, 2013), and who were heavy welfare users.

Parental financial support as well as debt problems were prevalent among the young adults who received social assistance, sickness benefit or labour-market subsidy. Heavy cash-welfare-benefit users were also particularly likely to receive parental financial support, and many of them also had debt problems. These findings imply that debt problems are associated not only with a low income and a low level of education (Oksanen et al. 2016), but also and especially with increasing reliance on cash-welfare benefits. Young adults with a low level of education who are not in the labour market may be more likely to have debt problems than those who are, or their debt problems may encourage them to stay out of the labour market because wages can be garnished ${ }^{10}$. This finding needs further investigation, however. In sum, our results revealed that many parents financially support their adult children to help them cope with their debt problems, and this support is often complementary to cash-welfare-benefits.

Students comprise an interesting group from the perspective of debt problems. Even if many of them have an extremely low income, and more than half (61\%) of those in higher education seem to have some or a lot of problems making ends meet (OKM 2014, 31), students seem to have fewer debt problems, on average, than young adults overall (Table 1). Parental financial support may be one factor behind their low level of debt problems, but there could be other explanations. Students are more familiar with having a low income than young adults who are working, or at least they manage it better if the indicator is a debt problem. Another reason may be related to their low living costs: housing, travelling and lunches are still quite generously subsidised by the Finnish welfare state.

Even if most parents financially support their adult children at some point in their lives, not all young adults have parents who are able or willing to do so. Overall, family background appears to create inequalities among young adults (Furlong \& Cartmel, 2007; Björnberg \& Latta, 2007). The educational level of parents is a strong determinant of their children's educational level: in other words, the children of more highly educated parents tend to be more highly educated than the children of parents with a lower level of education (see e.g. Kivinen et al., 2007). We found that the association between qualifications and parental financial support intensified when all the variables

\footnotetext{
${ }^{10}$ As a general rule, one third of wages, pensions, unemployment benefits and maternity benefits can be garnished. The garnished amount is calculated from the debtor's income net of tax. Social subsidies such as social assistance, housing allowances and child subsidies cannot be garnished (Oikeus.fi 2018).
}

This article is protected by copyright. All rights reserved. 
were included in the model. This result could imply that the more highly educated are also likely to receive parental financial support if they have debt problems. This needs further investigation, however.

Debt problems tend to be considered private matters that cause both economic and social harm over a long period of time (Patel et al., 2012). Quite small unpaid debts and loans can quickly extend beyond young adults' solvency, and thus have a long-term effect on their future prospects. Intervention is to be recommended before financial problems become too severe and difficult to solve, especially among young people who are in the transition phase to adulthood. Many young adults would benefit from easy access to loans with a long and flexible payback time and moderate interest if they have experienced unemployment or a relationship breakdown, for example. We also found that having dependent children and being out of the labour market were associated with debt problems and/or parental financial support. In the light of our findings we believe there should be an enhanced social-policy agenda especially for young adults who receive more than two different kinds of allowance: they, at least, could benefit from financial-management guidance and information about debt problems.

As with all research, this study is not without limitations. First, the data does not represent young adults in the Finnish population. Overall, not responding to questionnaires seems to be more common among men and those with a low educational level (Tolonen et al., 2006), in other words with groups with more debt problems, on average. Even so, we tried to consider the limitations in reporting our results. Second, it was not possible to discern from our data whether heavy benefit use is one factor behind debt problems, or vice versa. This chain of causality requires more careful consideration in future research. Third, the analysis would have benefited from more categories among those who were out of the labour market. Unemployed young adults are in a different financial position than those who are at home with children. Despite these limitations, this article shows how unemployment and having a child constitute risk factors for debt problems and create an enhanced need for parental or state financial support. We have also challenged the general assumption that students are particularly at risk of incurring debt by combining the two phenomena, debt problems and parental financial support, in one study.

Young adults in Finland are in a good situation in many ways if the focus is on parental financial support, debt problems or welfare-state support. Indeed, given our results one could argue that living in a Nordic welfare state and receiving parental financial support may help to prevent debt problems among young adults. This is not the whole picture, however. Debt problems were underestimated in the 'young adults and debts' data because of non-response bias: in other words, debt problems are more prevalent among young Finns than our results imply (see e.g. Suomen

This article is protected by copyright. All rights reserved. 
Asiakastieto Oy, 2017; Oksanen et al., 2015). According to Hiilamo (2018), for example, one structural cause of indebtedness in Finland is the instant loan, resembling the payday loan ${ }^{11}$. Indeed, it is revealed in a new study that young adults in particular are likely to receive court judgements for non-payment of instant loans (Majamaa et al., 2019). Given the availability of this form of credit not only in Finland but also throughout Europe and the USA, easy access to instant loans and other financial products may be a cause of increasing debt problems in the near future.

Finnish pupils and students have received more education on financial management since the new curriculum came into effect in autumn 2016. Even so, parents still constitute the major source of financial skills among young adults in Finland (Kaihari, 2018). This fosters inequality in that parents differ widely in terms of financial skills and competence. Raijas and Uusitalo (2012) have called for the Finnish Government to draw up a national strategy on financial education. It would help to smooth out the differences between young adults from different backgrounds, for example. Thus far, however, Finland is not among the growing number of countries that are developing national strategies for financial education.

In sum, young adulthood is a tricky time, financially and in general: ongoing studies and high youth unemployment adversely affect young people's financial independence (Furlong \& Cartmel, 2007). Debt problems are also very common among young adults (Oksanen et al., 2015). This study showed that many parents give financial support to help young adults with debt problems, even if parental obligations have usually been fulfilled once children reach the age of majority, at least in Finland. Even so, young adults without any qualifications, with a low income and with dependent children are highly susceptible. As the welfare state reduces its support, young adults such as these are likely to be exposed to new social risks (Taylor-Gooby, 2004), one significant outcome of which is debt problems.

\footnotetext{
${ }^{11}$ Instant loans amount typically from $€ 50$ to $€ 1,000$, expenses excluded. Since the repayment period is very short, usually a few weeks or months, the annual percentage rate of this unsecured consumer credit is typically well over $100 \%$. The easy-availability of instant loans have made them very popular in Finland.
}

This article is protected by copyright. All rights reserved. 


\section{References}

Aassve, A., Cottini, E., \& Vitali, A. (2013). Youth Vulnerability in Europe during the Great Recession. $\begin{array}{llll}\text { Working } & \text { Paper } & \text { Retrieved }\end{array}$ ftp://ftp.dondena.unibocconi.it/WorkingPapers/Dondena_WP057.pdf (accessed on April 3rd, 2017). Aassve, A., lacovou, M., \& Mencarini, L. (2006). Youth poverty and transition to adulthood in Europe. Demographic Research, 15, 21-50.

Albertini, M., \& Kohli, M. (2013). The generational contract in the family: An analysis of transfer regimes in Europe. European Sociological Review, 29(4), 828-840

Allon, F. (2015). Everyday leverage, or leveraging the everyday. Cultural Studies, 29(5-6), 687-706.

Barbieri, P., \& Bozzon, R. (2016). Welfare, labour market deregulation and households' poverty risks: An analysis of the risk of entering poverty at childbirth in different European welfare clusters. Journal of European Social Policy, 26, 99-123.

Becker, G. (1981). Altruism in the family and selfishness on the market place. Economica, New Series, 48(189), 1-15.

Becker, G. (1993). A Treatise on the Family. Enlarged edition. Cambridge, MA: Harvard University Press.

Bengtson, V. (1993). Is the "Contract Across Generations" Changing? Effects of Population Aging on Obligations and Expectations Across Age Groups. In The Changing Contract Across Generations (by V. Bengtson, \& W. Achenbaum), pp. 3-24. New York: Aldine de Gruyter.

Björnberg, U., \& Latta, M. (2007). The roles of the family and welfare state: the relationship between public and private financial support in Sweden. Current sociology, 55, 415-445.

Bonoli, G. (2007). Time matters: postindustrialization, new social risks, and welfare state adaptation in advanced industrial democracies. Comparative political studies, 40(5), 495-520.

Brandt, M. (2013). Intergenerational help a public assistance in Europe. A case of specialization? European Societies, 15, 26-56.

Esping-Andersen, G. (1990). The three worlds of welfare capitalism. Cambridge: Polity press.

Eurostat (2017). When are they ready to leave the nest? Retrieved from http://ec.europa.eu/eurostat/en/web/products-eurostat-news/-/EDN-20170503-1 (accessed on March 7th, 2018).

This article is protected by copyright. All rights reserved. 
Fritzell, J., \& Lennartsson, C. (2005). Financial transfers between generations in Sweden. Ageing \& society, 25, 397-414.

Furlong, A., \& Cartmel, F. (2007). Young people and social change. New perspectives. Berkshire: Open University Press.

Hiilamo, H. (2018). Household debt and economic crises: Causes, consequences and remedies. Edward Elgar, Cheltenham.

Kaihari, K. (2018). Nuorten talousosaaminen 2020. In Talouslukutaito 2020-luvulla: Maksuneuvoston e-kirjanen (by Bank of Finland), pp. 28-30. Retrieved from https://helda.helsinki.fi/bof/handle/123456789/15818

Kalmijn, M. (2013). How Mothers Allocate Support Among Adult Children: Evidence From a Multiactor Survey. Journal of Gerontology Series B: Psychological Sciences and Social Sciences, 68(2), 268-277.

Kangas, O. \& Kvist, J. (2013). Nordic welfare state. In The Routledge Handbook of the Welfare State (ed. by B. Greve), pp. 148-160. London: Routledge.

Kivinen, O., Hedman, J., \& Kaipainen, P. (2007). From elite university to mass higher education. Educational expansion, equality of opportunity and returns to university education. Acta Sociologica, 3, 231-247.

Kohli, M. (1999). Private and public transfers between generations: Linking the family and the State. European Societies, 1, 81-104.

Kohli, M., \& Künemund, H. (2003). Intergenerational transfers in the family. What motivates giving? In Global aging and challenges to families (eds. by V. Bengtson, \& A. Lowenstein), pp. 123-142. New York: Aldine de Gruyter.

Majamaa, K. (2011). Dismissed intergenerational support? New social risks and the economic welfare of young adults. Journal of Youth Studies 14(6), 729-743.

Majamaa, K. (2012). The effect of socio-economic factors on parental financial support from the perspectives of the givers and the receivers. European Societies, 15, 57-81.

Majamaa, K. (2015). Who receive parental help? Parental financial support and practical help for adult children from the perspectives of givers and receivers. PhD diss., University of Helsinki. Retrieved from https://helda.helsinki.fi/handle/10138/152713

Majamaa, K.; Lehtinen, A-R., \& Rantala, K. (2019). Debt judgments as a reflection of consumptionrelated debt problems. Journal of Consumer Policy. https://doi.org/10.1007/s10603-018-9402-3.

This article is protected by copyright. All rights reserved. 
Majamaa, K., \& Rantala, K. (2016). Nuorten aikuisten velat, velkaongelmat ja keinot talouden tasapainottamiseksi. Institute of Criminology and Legal Policy, University of Helsinki. Report $16 / 2016$.

Mendola, D., Busetta, A., \& Aassve, A. (2009). What keeps young adults in permanent poverty? A comparative analysis using ECHP. Social Science Research, 38, 840-857.

Moisio, P. (2008). Köyhyyden ja toimeentulo-ongelmien kehitys. In Suomalaisten hyvinvointi 2008 (ed. by P. Moisio, S. Karvonen, J. Simpura, \& M. Heikkilä), pp. 256-275. Stakes.

Myllyniemi, S. (2015). Tilasto-osio. Arjen jäljillä. Nuorisobarometri 2015 (ed. by S. Myllyniemi), pp. 9107. Ministry of Education and Culture, Finnish Youth Research Society. Grano Multiprint, Helsinki.

Oikeus.fi (2018). Attachment of salary. Retrieved from https://oikeus.fi/ulosotto/en/index/velallisenaulosotossa/palkanulosmittaus.html (accessed on November 6th, 2018).

OKM (Ministry of Education and Culture) (2014). Opiskelijatutkimus 2014. Korkeakouluopiskelijoiden toimeentulo ja opiskelu. Publications of the Ministry of Education and Culture 2014:10. Retrieved from http://www.minedu.fi/export/sites/default/OPM/Julkaisut/2014/liitteet/okm10.pdf?lang=fi.

Oksanen, A., Aaltonen, M., \& Rantala, K. (2015). Determinants of Debt Problems in a Nordic Welfare State: a Finnish Register-Based Study. Journal of Consumer Policy, 38, 229-246.

Oksanen, A., Aaltonen, M., \& Rantala, K. (2016). Debt problems and life transitions: a register-based panel study of Finnish young people. Journal of Youth Studies, 19, 1184-1203.

Patel, A., Balmer, N., \& Pleasence, P. (2012). Debt and disadvantage: the experience of unmanageable debt and financial difficulty on England and Wales. International Journal of Consumer Studies, 36, 556-565.

Raijas, A. \& Uusitalo, O. (2012). Tutkimushankkeen tulosten hyödynnettävyys. In Nuoret ja talousosaaminen. Toimijat, kanavat ja tavat nuorten taloudellisen osaamisen edistämisessä (TOKATA) -hankkeen loppuraportti (by A. Raijas, \& O. Uusitalo), pp. 65-79. Retrieved from https://helda.helsinki.fi/handle/10138/152329

Rossi, A. \& Rossi, P. (1990). Of human bonding. Parent-child relations across the life course. New York: Aldine de Gruyter.

Sahlins M. (1972). Stone Age Economics. Chicago: Aldine.

This article is protected by copyright. All rights reserved. 
Silverstein, M., Conroy, S., \& Gans, D. (2012). Beyond solidarity, reciprocity and altruism: moral capital as a unifying concept in intergenerational support for older people. Ageing and Society, 32(7), $1246-1262$.

Social Insurance Institution of Finland (2018). Types of expenses for which you can get basic social assistance. Retrieved from https://www.kela.fi/web/en/social-assistance-types-of-expenses-forwhich-you-can-get

Statistics Finland (2016a). Income distribution statistics. Retrieved from http://pxnet2.stat.fi/PXWeb/pxweb/en/StatFin/StatFin_tul_tit/283_tjt_tau_054.px/?rxid=d7ea10 50-4fb2-4d3c-8b27-c174317e1006 Helsinki: Statistics Finland.

Statistics Finland (2016b). Educational structure of population in 2015. Retrieved from http://tilastokeskus.fi/til/vkour/2015/vkour_2015_2016-11-03_fi.pdf Helsinki: Statistics Finland.

Statistics Finland (2017). Enforcement matters. Retrieved from http://pxnet2.stat.fi/PXWeb/pxweb/fi/StatFin/StatFin_oik_uloa/statfin_uloa_pxt_003_fi.px/?rxid =3eb2f671-0f4c-4c30-b64f-a627a15d26f8 Helsinki: Statistics Finland.

Statistics Finland (2018). One-third of person's at-risk-of-poverty are young adults. Retrieved from https://www.tilastokeskus.fi/til/tjt/2016/01/tjt_2016_01_2018-03-02_tie_001_en.html Helsinki: Statistics Finland.

Suomen Asiakastieto Oy (2017). Maksuhäiriötilastot 2016. Retrieved from http://www.mynewsdesk.com/fi/asiakastieto/documents/suomen-asiakastieto-oymaksuhaeirioetilastot-2016-63266

Swartz, T., \& O'Brien, K. (2009). Intergenerational support during the transition to adulthood. In Handbook of Youth and Young Adulthood: New Perspectives and Agendas (ed. by A. Furlong), pp. 217-225. Routledge, London.

Taylor-Gooby, P., (2004). New risks and social change. In New risks, new welfare: the transformation of the European welfare state (ed. by P. Taylor-Gooby), pp. 1-28. Oxford University Press, Oxford.

Tolonen, H., Helakorpi, S., Talala, K., Helasoja, V., Martelin, T., \& Prättälä, R. (2006). 25-year trends and socio-demographic differences in response rates: Finnish adult health behaviour survey. European Journal of Epidemiology, 21, 409-415.

Townley-Jones, M., Griffiths, M., \& Bryant, M. (2008). Chronic consumer debtors: the need for specific intervention. International Journal of Consumer Studies, 3, 204-210.

This article is protected by copyright. All rights reserved. 
Xiao, J.J., Chatterjee, S., \& Kim, J. (2014). Factors associated with financial independence of young adults. International Journal of Consumer Studies, 38, 394-403.

Worthy, S.L., Jonkman, J., \& Blinn-Pike, L. (2010). Sensation-seeking, risk-taking, and problematic financial behaviors of college students. Journal of Family and Economic Issues, 31, 161-170.

\begin{tabular}{|c|c|c|c|c|c|c|c|}
\hline Young adults & & $\begin{array}{c}\text { Debt } \\
\text { problems }\end{array}$ & $\begin{array}{l}\text { Parental } \\
\text { financial } \\
\text { support }\end{array}$ & Table continues & & $\begin{array}{c}\text { Debt } \\
\text { problems }\end{array}$ & $\begin{array}{l}\text { Parental } \\
\text { financial } \\
\text { support }\end{array}$ \\
\hline & $\%$ & Yes (\%) & Yes (\%) & & $\%$ & Yes (\%) & Yes (\%) \\
\hline Age group & & & & Main type of activity & & & \\
\hline $18-21$ years old & 27.3 & 8.9 & 78.9 & Mainly working & 33.2 & 12.4 & 37.8 \\
\hline $22-25$ years old & 27.1 & 13.1 & 66.8 & Mainly studying & 29.0 & 6.1 & 72.4 \\
\hline $26-30$ years old & 26.0 & 12.0 & 52.6 & Studying and also employed & 16.2 & 6.9 & 63.0 \\
\hline $31-35$ years old & 19.6 & 13.6 & 32.8 & Out of the labour market & 21.6 & 22.1 & 73.9 \\
\hline Gender & & & & Disposable income per month & & & \\
\hline Men & 36.6 & 12.4 & 52.7 & Less than $€ 500$ & 18.9 & 11.4 & 76.9 \\
\hline Women & 63.4 & 11.4 & 63.8 & $€ 500-€ 999$ & 29.1 & 14.6 & 73.3 \\
\hline Type of household & & & & $€ 1,000-€ 1,999$ & 26.6 & 13.4 & 53.4 \\
\hline Alone & 30.6 & 13.8 & 64.9 & $€ 2,000$ or more & 25.4 & 5.9 & 27.1 \\
\hline With spouse & 44.5 & 10.5 & 50.1 & Number of received social secu & eefits & & \\
\hline With parent(s) & 12.3 & 5.4 & 70.3 & None & 32.3 & 8.6 & 41.9 \\
\hline Other & 12.5 & 17.7 & 70.8 & 1 benefit & 20.5 & 9.2 & 53.5 \\
\hline Children & & & & 2 benefits & 34.1 & 7.8 & 73.6 \\
\hline No children & 83.9 & 9.8 & 62.8 & At least 3 benefits & 13.1 & 33.9 & 77.1 \\
\hline At least one child & 16.1 & 22.1 & 43.5 & Debt problems & & & \\
\hline Qualifications & & & & No & 88.2 & & 57.1 \\
\hline Vocational school or less & 25.5 & 28.3 & 57.4 & Yes & 11.8 & & 69.3 \\
\hline Matriculation examination & 36.5 & 8.8 & 71.4 & All & 100.0 & 11.8 & 59.7 \\
\hline At least university of applied sciences & 38.0 & 3.5 & 50.0 & $\mathbf{N}$ & 901 & 901 & 901 \\
\hline
\end{tabular}

Source: Young adults and debts

This article is protected by copyright. All rights reserved. 
Table 2 Percentages of young adults with debt problems and receiving parental financial support ( $n=901)$

\begin{tabular}{|c|c|c|}
\hline Cash-welfare-benefits & $\begin{array}{c}\text { Debt problems } \\
(\%)\end{array}$ & $\begin{array}{c}\text { Parental } \\
\text { financial } \\
\text { support (\%) }\end{array}$ \\
\hline Earnings-related unemployment benefit $(n=57)$ & 14.0 & 56.1 \\
\hline Basic unemployment benefit $(n=65)$ & $33.9 * * *$ & $70.8+$ \\
\hline Labour-market subsidy $(n=53)$ & $22.6 *$ & $79.3^{* *}$ \\
\hline Student grant $(n=377)$ & $7.4 * *$ & $72.2 * * *$ \\
\hline Student housing allowance $(n=301)$ & $6.6^{* *}$ & $75.4 * * *$ \\
\hline General housing allowance $(n=131)$ & $35.9 * * *$ & $79.4 * * *$ \\
\hline Social assistance $(n=77)$ & $63.6^{* * *}$ & $80.5^{* * *}$ \\
\hline Sickness benefit $(n=31)$ & $29.0 * *$ & $80.7 *$ \\
\hline Child benefit ( $n=109)$ & $22.9 * * *$ & $45.9 * *$ \\
\hline Child maintenance allowance / child support $(n=25)$ & $48.0 * * *$ & 52.0 \\
\hline Maternity / paternity allowance $(n=39)$ & 15.4 & $41.0 *$ \\
\hline Parental allowance $(n=25)$ & 12.0 & 48.0 \\
\hline Child home-care allowance $(n=30)$ & 10.0 & 53.3 \\
\hline Survivor's pension $(n=4)$ & 0.0 & 75.0 \\
\hline None $(n=222)$ & $5.4^{* *}$ & $40.5^{* * *}$ \\
\hline All $(n=901)$ & 11.8 & 59.7 \\
\hline Source: Young adults and debts & & \\
\hline
\end{tabular}

This article is protected by copyright. All rights reserved. 


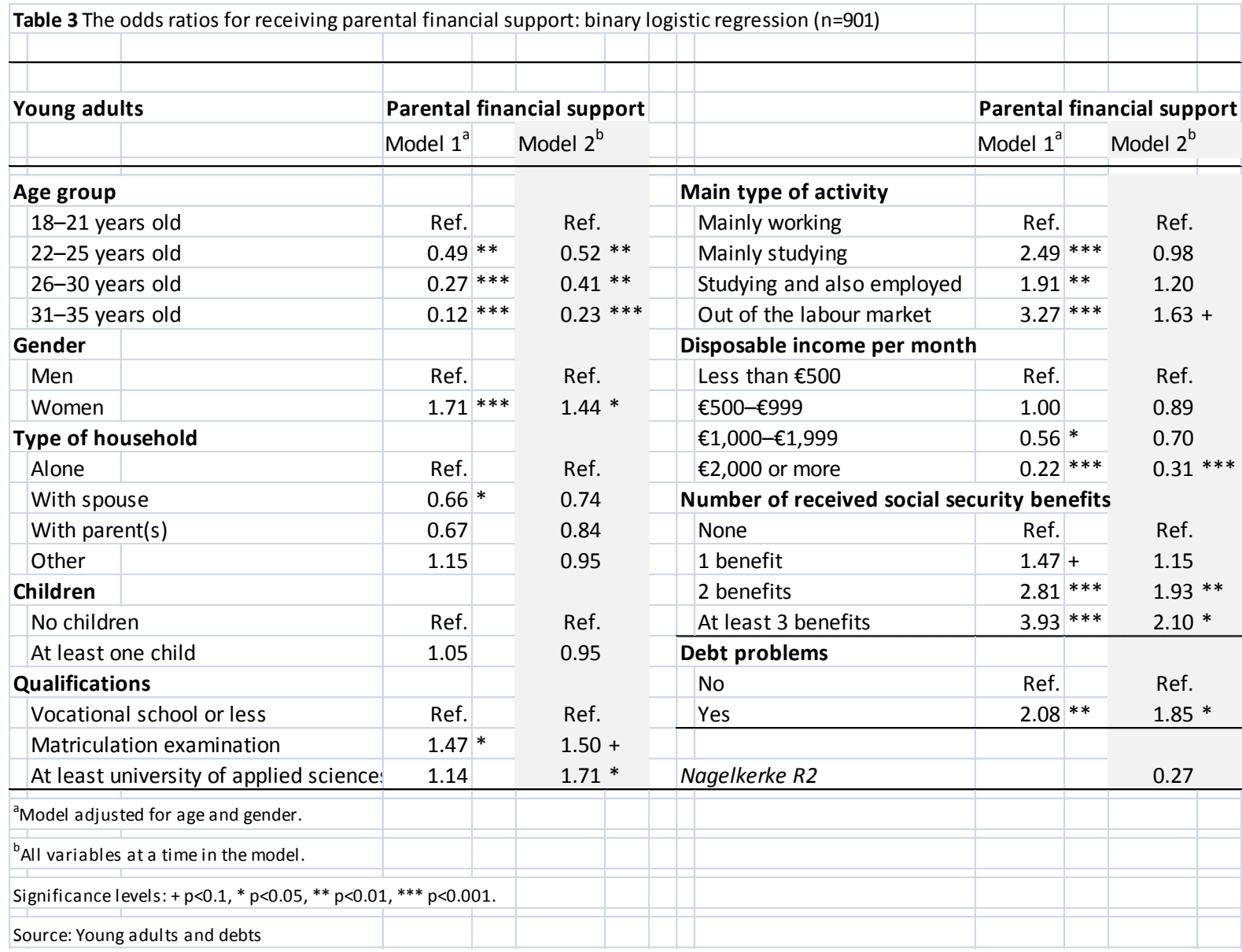

This article is protected by copyright. All rights reserved. 